\title{
Genetic diversity of the European oyster (Ostrea edulis L.) in Nova Scotia: Comparison with other parts of Canada, Maine and Europe and implications for broodstock management
}

\author{
Bénédikte Vercaemer ${ }^{1}$, Koren R. Spence ${ }^{1}$, Christophe M. Herbinger ${ }^{2}$, Sylvie \\ Lapègue $^{3}$ and Ellen L. Kenchington ${ }^{1}$
}

1. Fisheries and Oceans Canada, Ecosystem Research Division, Bedford Institute of Oceanography, 1 Challenger Drive, Dartmouth, Nova Scotia, B2Y 4A2, Canada

2. Dalhousie University, Department of Biology, Halifax, Nova Scotia B3H 4J1, Canada

3. IFREMER, Station de la Tremblade, Laboratoire Génétique et Pathologie B.P. 133, 17390 La

Tremblade, France

\begin{abstract}
The European oyster (Ostrea edulis) was introduced to the Nova Scotia aquaculture industry 30 years ago using stocks imported from naturalized populations in Maine whose ancestors originated in the Netherlands. This study used 5 microsatellites to assess the level of genetic diversity in several hatchery stocks and naturalized populations from Nova Scotia, New Brunswick, British Columbia and Maine. Some genetic erosion was shown to have occurred in the Maritimes populations, with the largest loss of alleles being experienced by the hatchery stocks. In spite of this loss, genetic diversity and heterozygosity in the Maritimes populations are still relatively high. Relationships within and between the populations and the existence of kin groups within the collections were overall consistent with our knowledge of the historical transfers of oysters between different locations. Furthermore, the established database allowed to assign with good confidence unknown oyster samples to their geographic origin. This would be a useful forensics tool in the case of an illegal transfer from a diseased area.
\end{abstract}

KEY WORDS Ostrea edulis, European oyster, flat oyster, microsatellites, Maine, genetic diversity 


\section{INTRODUCTION}

European oysters (Ostrea edulis) were introduced to Nova Scotia 30 years ago, principally from naturalized Maine populations whose ancestors originated in the Netherlands in 1949 (Loosanoff, 1955; Welsh, 1964; Newkirk et al., 1995). They were brought to Nova Scotia to develop oyster aquaculture in the cool, high salinity areas on the Atlantic coast of the province. These waters are generally too cold in the summer to ensure reproductive success of the native American oyster Crassostrea virginica which subsists in only a few small isolated populations in estuaries and tidal lakes (Spares \& Dadswell, 2001). Growing conditions for O. edulis are good in the waters off the Atlantic coast of Nova Scotia but spawning conditions are only marginal in most sites. In addition, the summer season is relatively short, yet good spat growth is essential for ensuring subsequent winter survival. However in a few locations, European oysters have managed to naturalize and have established apparently sustainable populations. Nevertheless, the development of the European oyster industry in Nova Scotia over the past 30 years has relied exclusively upon hatchery produced spat that are transferred to grow-out sites at the end of summer/beginning of fall.

There are now separate groups of European oysters in Nova Scotia that may be genetically differentiated to various degrees due to human and environmental influences (e.g. severe winter mortalities in 1990/91 and in 1991/92 or bottlenecks in hatcheries). In addition, the parasite Bonamia ostreae is known to be endemic in the European oyster population of Maine but is not present in Nova Scotia. This disease devastated the French oyster industry in 1979 and could have similar devastating consequences if introduced to Nova Scotia, one of the last places in the world where this disease has not 
been reported. Any importation of new oysters from Maine or other sources is consequently prohibited for this reason.

The preservation and utilization of genetic variability in any broodstock program is a critical and complex issue. Numerous studies have shown that genetic variations can be lost at a rapid rate in hatcheries leading to inbreeding increase and depression (e.g. Beattie et al., 1987; Hedgecock \& Sly, 1990; Naciri-Graven et al., 2000, see review in Herbinger et al., 2003). In 2001, larvae and spat started to experience massive mortalities in Nova Scotia's hatcheries. Water quality, such as variation in temperature or organic / bacterial load, was suspected to be responsible for the problems, but the possibility of genetic erosion and concomitant increase in inbreeding, coupled with the inability to import new genetic material to Nova Scotia, was also a serious concern. This study was thus concerned with characterizing the present level of genetic variability observed both in hatchery and naturalized stocks, the latter being a potential source of Bonamia-free broodstock to counteract potential serious losses of diversity in the former. The existing genetic variability and differentiation of various groups of naturalized populations and hatchery stocks of oysters in Nova Scotia was assessed using five microsatellite DNA markers, in comparison with hatchery or endemic $O$. edulis populations in other parts of Canada, Maine and Europe. This study also used DNA marker based pedigree reconstruction to detect the presence of related individuals among any of the groups, as evidence of on-going genetic bottleneck, and evaluated whether the same microsatellite DNA information could be used to detect illegal importation of oysters from Maine. 


\section{MATERIALS AND METHODS}

\section{Collection of populations}

Gill or mantle tissue was collected from adult Ostrea edulis oysters (> 3 years old) using non-lethal sampling techniques (biopsy), and was preserved in $95 \%$ ethanol or by freezing at $-20^{\circ} \mathrm{C}$ until DNA was extracted. Samples were taken from 10 sites in 2002 and 2003, which included hatchery stocks from Nova Scotia and British Columbia as well as naturalized populations in Maine (Welsh, 1964), New Brunswick and Nova Scotia (Figure 1). Figure 1 also summarizes what is known about the various transfer and founding events associated with these populations within Nova Scotia and New Brunswick. As is frequently the case, many of the founding events and transfers are poorly documented. The Maine naturalized populations resulted from the importation of Netherlands oysters in the 1950's (Welsh, 1964). In the 1960's, interest in O. edulis cultivation developed and several small hatcheries and oyster farms established themselves around the naturalized populations in Maine. The Boothbay and Cundy Harbor populations are older naturalized populations while the Blue Hill Bay population is a more recent "naturalized" population that originated from importations from Boothbay Harbor and from California (Sam Chapman, pers. comm.).

After a small scale unsuccessful importation in the late 1960s - early 1970's from Maine to Nova Scotia, new naturalized oysters from Maine, and a few from North Wales, were imported in 1978 and 1979 to the Dalhousie University hatchery (Halifax, Nova Scotia) (Newkirk, 1986). In 1989 and 1994, respectively, the Dalhousie University and 
Nova Scotia provincial hatcheries closed and the broodstock was passed on to a total of four small commercial hatcheries, which, in conjunction with several grow-out operations have maintained most of the O. edulis cultured populations in Nova Scotia. In one growout site (Sambro), a small sustainable natural population managed to establish itself and has survived despite the closure of the grow-out operation. O. edulis were also found in Blind Bay, another former grow-out site. However, in this case, no juvenile oysters were recovered, and the few large oysters found appeared to be the last surviving oysters from the grow-out site after its closure. In 1996/1997, a naturalized population was established in Lake Lockhart, New Brunswick with oysters derived from the last two hatcheries left in Nova Scotia (Port Medway and Lunenburg). The Lake Lockhart population has grown rapidly and undergone two generations in the wild. It is the largest naturalized European oyster population in the Maritimes region of Canada. The Pacific Coast stock, sampled for comparison purposes, is a hatchery maintained stock of a mixed and poorly documented origin. Transfers have occurred in the last 20 years with individuals originating from California, Scotland and Maine probably via Nova Scotia.

\section{Amplification and visualization of microsatellites}

To prepare the samples for DNA extraction, frozen tissue was thawed at room temperature. Both frozen and ethanol-preserved samples were rinsed in distilled water to remove residual salt from the tissue. DNA was extracted using DNeasy Tissue Kits, following the manufacturer's instructions (Qiagen cat \#69506).

Polymerase Chain Reaction (PCR) was used to amplify five variable tandem repeat loci (microsatellites): four dinucleotides OeduU2, OeduT5, OeduO9, and 
OeduJ12, and one tetranucleotide, OeduH15 developed at IFREMER (Launey, 1998; Launey et al., 2002). Primers were labeled at the 5' end with a fluorescent dye. A $8 \mu$ of reaction mix (10 $\mu \mathrm{M}$ of each primer, $15 \mathrm{mM} \mathrm{MgCl}_{2}, 1 \mu \mathrm{l} 10 \mathrm{x}$ buffer, $1 \mu \mathrm{l}$ dNTP mix, and 0.5 u Taq polymerase) was added to $20-40 \mathrm{ng}$ of DNA from the extraction. PCR amplification was performed using a MJ Research Dyad thermocycler (model PTC-220). A touchdown PCR was used to increase the specificity of the reaction (cycling conditions: an initial denaturation step at $94^{\circ} \mathrm{C}$ for $2 \mathrm{~min}$, followed by 1 cycle at target annealing temperature $\left(T_{a}\right)+5^{\circ} \mathrm{C}$ for $1 \mathrm{~min}$, with subsequent decrease of $1^{\circ} \mathrm{C} / \mathrm{cycle}$ for the next 4 cycles, with the remaining 25 cycles at $\mathrm{T}_{\mathrm{a}}$ and a final 5 min extension at $72^{\circ} \mathrm{C}$ )

PCR products were electrophoresed on a $0.075 \mathrm{~mm} 5 \%$ denaturing polyacrylamide gel with an internal size standard (Megabase ET-400, AmershamPharmacia cat \#25-0205-01) added to each lane. Electrophoresis and visualization of alleles were performed using a MJ Research BaseStation Fragment Analyzer. Alleles were assigned scores (size in base pairs) by comparing them to the internal size standard using Cartographer software (Cartographer v 1.2.6, MJ Research). To standardize scores obtained in this study with Launey (2002)'s study, 12 individuals genotyped at the IFREMER station in France on a Licor platform were selected for their wide range of allele sizes at each locus. These individuals, were also genotyped on the MJ Research BaseStation in Canada. The scores obtained from the two different platforms were compared and adjustments were made if required. Only two microsatellite markers (OeduJ12 and OeduH15) could be unambiguously standardized over the complete range of allele sizes. 


\section{Data Analysis}

Observed and unbiased expected heterozygosities, F-statistics, and genetic distances were calculated with the program GENETIX (Belkhir et al., 1996-2004) and the program CONTRIB (Petit, 1998) was used to calculate allelic richness corrected for differing sample size. The software MICRO-CHECKER (Van Oosterhout et al., 2004) was used to check for the potential presence of null allele and genotyping errors in the data set. PHYLYP (Felsenstein, 1993) was used for drawing phylogenetic trees among the various populations. Phylogenetic analyses were based on all five loci when looking at genetic differentiation among the North American collections alone, but were based on two loci (OeduH15 and OeduJ12) when using the European populations genotype data collected in an earlier work (Launey, 1998; Launey et al., 2002).

In addition, ten oysters from each of the three Maine collections were selected at random and removed from the database. These 30 oysters were then treated as an "unknown" sample to see to which populations they would be assigned on the basis of their genetic profiles using GENECLASS (Cornuet et al., 1999). The computation is based on a likelihood method using a Bayesian approach and gives for each individual a list of populations for which the "probability of belonging" is larger than a chosen threshold. We used the default probability of 0.01 .

Lastly, DNA marker based pedigree reconstruction among the various collections of oysters was undertaken using Pedigree 2.2, a much expanded version of the pairwise score method (Smith et al. 2001, Butler et al., 2004), accessible online at 
http://herbinger.biology.dal.ca:5080/Pedigree. This approach to first generation pedigree reconstruction uses a highly efficient Markov Chain Monte Carlo algorithm to sample the space of possible partitions and to maximize an overall partition score based on the logarithm of pairwise likelihood ratios of being full-sib or unrelated. A partition is an allocation of all individuals into putative groups. Here, the individuals in the various oyster collections were allocated into putative kin groups, where a kin group contains individuals that appear related based on the DNA marker data but without imposing a particular type of relationship among the individuals. Individuals within kin groups are typically a mixture of full-sibs and half-sibs. This analysis was performed only on individuals with at least 4 loci genotyped and used the following MCMC parameters: $3,000,000$ iterations, annealing temperature of 10 and a weight of 1 , since the various data sets did not appear to contain large family groups (see help manual available at http://herbinger.biology.dal.ca:5080/Pedigree).

Most pedigree reconstruction algorithms tend to assemble, by chance, unrelated individuals into small artefactual groupings (Smith et al. 2001, Butler et al., 2004). To test whether the kin group partitions generated for each oyster collections may contain at least a few truly related individuals, 100 genotype randomization trials were performed, followed by kin group reconstruction for each data set. This created 100 sets of unrelated individuals sampled from populations with the same genotypic frequencies as in our original datasets. The overall significance ( $p$-value) of a kin partition was evaluated by the proportion of the 100 randomised trials with a partition score as high or higher than the observed score. 


\section{RESULTS AND DISCUSSION}

\section{Allelic variability, allelic richness corrected for sample size and allelic frequencies}

The five microsatellite loci used in this study were all found to be highly polymorphic. Allelic richness is highly dependent on effective population size (Nei et al., 1975) and should be a good indicator of past demographic changes (Petit et al., 1998). The number of alleles found at each locus ranged from 14 (OeduH15) to 29 (OeduU2), with a mean of 22.8 .

Table 1 compares the observed number of alleles in the Canadian, Maine, and Northern European populations overall. The observed number of alleles was lower in the Maine populations compared to the Northern European populations (data from Launey, 1998) at four of the five loci used in this study. The loss ranged from three alleles $(\mathrm{OeduH} 15)$ to five alleles (OeduU2). The Canadian populations showed an even greater loss of allelic diversity, ranging from three alleles $(\mathrm{OeduH} 15)$ to nine alleles (OeduO9), when compared to the Northern European populations. This was true despite the fact that the sample size for the Canadian populations was much larger than both the Maine and European populations.

When the Canadian populations were compared to the Maine population, there was a loss of alleles at 3 loci: 2 alleles at OeduU2, 6 at OeduT5, and 5 at OeduO9. There was no loss of alleles at OeduH15, and a "gain" of an allele at OeduJ12. This "gain" is likely an artifact due to the lower number of individuals from Maine. 
Direct comparisons of allelic richness between populations was difficult due to the large range in sample sizes (30 to 148), as larger samples will have a greater chance of including rare alleles. The program CONTRIB was used to correct for differences in sample size. Table 2 illustrates the amount of genetic diversity present in each of the sampled populations by showing the actual and corrected numbers of alleles at each locus. The NS hatchery stocks had a mean corrected number of alleles ranging from 9.91 (Port Medway) to 10.32 (Lunenburg). The British Columbia hatchery stock was slightly more diverse (11.20), and Maritimes naturalized populations varied from 8.88 (small "naturalized" Blind Bay group, which shows the lowest mean number of corrected number of alleles) to 12.81 (Lake Lockhart) alleles. The Maine populations ranged from 12.43 (Blue Hill Bay) to 15.29 (Boothbay Harbor).

At each locus, evidence of some genetic erosion can be seen with smaller number of alleles observed in the Canadian collections. Compared to the 2 larger Maritimes naturalized populations (Sambro, NS and Lake Lockhart, NB) and to the Maine naturalized populations (Cundy's Harbor, Boothbay Harbor and Blue Hill Bay), the combined Nova Scotian hatchery stocks (Lunenburg, Port Medway and Cape Sable) showed the lowest number of alleles at all loci, with a mean of 13.6 alleles for all loci. The Maritimes naturalized populations showed a mean of 17.6 alleles and the Maine populations a mean of 21.6 alleles. Nevertheless, the actual number of alleles at each locus was still relatively high in the Nova Scotia hatchery stocks. 
Some degree of on-going genetic erosion is therefore taking place in the artificially propagated populations of Ostrea edulis, but it would appear that, as of 200203, there is still a substantial level of genetic diversity in the Canadian collections, despite the fact that these populations have been isolated from both their ancestral European and Maine populations, and have been propagated in hatcheries for several generations. As a comparison, in O. edulis French populations selected for Bonamia resistance, the mean number of alleles was reduced from 19.8 (natural population) to a range of 5.4 to 12.8 (selected populations) in two generations (Launey et al., 2001). The Canadian populations seem to have experienced considerably less erosion of allelic richness in 6 to 7 generations since their importation from Maine. In other words, genetic erosion could have been more drastic than was revealed in this study.

Genetic erosion is a common concern for hatchery stocks. An estimation of the breeding number of oysters in hatchery Crassostrea virginica MSX resistant lines varied from 4 to 16 (Hedgecock et al., 1992). Hatchery-propagated Pacific oysters have also lost alleles in three generations and one hatchery stock showed a per-generation effective population size of 9 oysters (Hedgecock \& Sly, 1990). Boudry et al. (2002) showed that effective population size was strongly reduced compared to census size in Crassostrea gigas because of unbalanced parental contribution. For O. edulis, Launey et al. (2001) estimated that the effective size of oyster populations selected for Bonamia resistance was very low, between 3 and 20 at the most. In the present study, effective population size $\mathrm{N}_{\mathrm{e}}$ could not be determined but was probably higher than in the populations studied by Launey et al. (2001). Alvarez et al. (1989) and Saavedra \& Guerra (1996) previously reported the number of effective O. edulis broodstock to be 6- 
10 and 3-4 from mass spawning tanks containing 60 and 120 animals respectively. This evidence shows that $O$. edulis is a species susceptible to founder and bottleneck effects in the hatchery environment and that genetic erosion has to be carefully monitored.

In this study, the allelic richness corrected for unequal sample size clearly indicated that the Lake Lockhart population was the most diverse in the Canadian collections. This is probably due to the fact that it is a relatively large, truly naturalized population. Although sampled from the wild, the Blind Bay population did not appear as variable as the two other naturalized Nova Scotian populations. This is a probable indication that it is not a truly naturalized population. Divers at this site did not find any juvenile oyster or any sign of recruitment. The few large oysters found there were probably the last survivors of the previous cultivated oysters. The 5 remaining Canadian populations appeared similar, with possibly a slightly higher diversity in the Pacific Coast stock. Repeated transfers have occurred in the last 20 years with individuals originating from different populations in California, Scotland and Maine, possibly explaining the higher diversity in this hatchery stock.

The allelic profiles for each locus showed multimodal distributions both in the Maine population and the Canadian population as they did in Europe (Launey, 1998). Only the distribution for OeduO9 was close to a normal distribution in a European sample of 507 individuals (Launey, 1998). There was no major discontinuity in the distributions and increments corresponded to the repeat length for a given locus (dinucleotide for all loci except OeduH15, which is a tetranucleotide locus). However the various collections showed differences in the abundance of rare alleles (frequency < 
$10 \%)$. A high level of rare alleles (87\% average over 5 loci) characterized the Maine population, while the Maritimes naturalized populations and hatchery stocks showed lower levels of $73 \%$ and $69 \%$ respectively. The hatchery populations lost 5, 2, 7, 8 and 2 rare alleles at loci OeduU2, OeduH15, OeduT5, OeduO9 and OeduJ12 respectively compared to the naturalized populations. These results are usually observed when a population experiences a bottleneck event but may also reveal subsequent genetic erosion.

\section{Heterozygosity}

The observed heterozygosity $\left(\mathrm{H}_{0}\right)$ was lower than the expected heterozygosity $\left(\mathrm{H}_{\mathrm{e}}\right)$ for all populations (Table 3), a typical observation in bivalves (Hedgecock et al., 1992, Hedgecock \& Okazaki, 1984). The difference between $H_{e}$ and $H_{0}$ was smallest in the British Columbia and Port Medway samples. This may be a result of a breeding program for certain traits that has led to the incidental selection of heterozygotes, or may possibly be an artifact of the sampling procedure, as the sample sizes for these populations were both relatively small.

When looking at the hatchery stocks (Table 3), levels of heterozygosity were not as dramatically reduced as allelic richness was. The average observed heterozygosity $\left(\mathrm{H}_{0}\right)$ for each population ranged from 0.670 (Lunenburg) to 0.827 (British Columbia) and no apparent association between the observed heterozygosity and the origin of the samples (hatchery versus naturalized) was observed. Similar results have been reported for many cultivated populations (Herbinger et. al. 2003); in particular an earlier 
study on Crassostrea gigas showed that the number of alleles was significantly reduced but heterozygosity was retained in hatchery stocks compared with naturalized populations (Hedgecock \& Sly, 1990; Herbinger et. al. 2003).

The $F_{\text {is }}$ values for the five loci, all populations combined, ranged from -0.094 (OeduT5) to +0.585 (OeduH15) (Table 3), which represents a large range of values. The estimated $F_{\text {is }}$ values varied much less among samples (from +0.040 to +0.179 ) than among loci. This result indicates that inbreeding is not the sole explanation for the heterozygote deficiencies. All populations showed mostly positive $F_{\text {is }}$ values revealing deficits in heterozygosity, but this was really mostly prevalent for loci OeduH15 and OeduJ12 (Table 3). Such observations are common in bivalves (Zouros \& Foltz, 1984) and the same pattern was observed in the European populations (Launey, 1998). This is likely due mostly to the presence of null alleles (alleles that are not amplifying, possibly due to a mutation in the primer site). Indeed, MICRO-CHECKER revealed the probable presence of null alleles for OeduH15 and OeduJ12 in nearly all populations. Launey (1998) also hypothesized that null alleles were present for the locus OeduH15. O. edulis natural populations have high fecundity and potentially large dispersal of gametes and larvae, and so should follow the HWE assumptions for panmixia. In the context of the hatchery propagated populations, heterozygotes deficit could possibly also reflect blind selection effects, along with small reproductive population size and inbreeding (Hedgecock, 1994). However, given the relative similarities of the $F_{\text {is }}$ values observed in naturalized and hatchery population, it would appear that the presence of null alleles at loci OeduH15 and OeduJ12 are the main reasons for the observed heterozygote deficiencies here. 


\section{Genetic differentiation between European oyster populations}

The genetic differentiation between populations revealed by the pairwise $\mathrm{F}_{\mathrm{ST}}$ values are displayed in Table 4. Most of the $F_{S T}$ values under 0.027 were not significant and indicated negligible genetic differentiation. This can be illustrated graphically with an unrooted tree constructed using the co-ancestry distances (Reynolds et al., 1983) (Figure 2a). The Maine populations clustered together with the Pacific Coast population, probably reflecting the founding events that led to the establishment of the Pacific Coast population through the transfer of oysters from California, Scotland and Maine. Despite their recent origin, the Maritimes populations (Port Medway, Lunenburg, Lake Lockhart and Cape Sable) clustered together and were quite divergent from the Maine populations. The intermediate position of the Sambro oysters possibly reflects the fact that they are an older re-naturalized population consisting of Maine oysters that were maintained at Dalhousie University in Halifax for several years before being released. The close clustering of the Nova Scotian populations is explained by their recent common ancestry and the exchanges of individuals that have taken place between these populations. For example, the fact that the Lake Lockhart and Lunenburg populations cluster closely together reflects the fact that the Lake Lockhart population was established using mainly oysters from Lunenburg stocks.

The Northern American flat oyster populations were compared with 5 European populations of flat oysters representing four subregions of the sampling realized in Launey et al. (2002), (ANa from Oslofjorden, Norway (North Atlantic); ANb from 
Grevelingen, Netherlands (North Atlantic); ASb from La Rochelle, France (South Atlantic); MWb from Thau Lagon, France (West Mediterranean Sea); MEb from Dubrovnik, Croatia (East Mediterranean Sea)). The analyses were based on the two microsatellite markers (OeduJ12 and OeduH15) that could be unambiguously standardized between the genotyping systems from the Canadian and French molecular laboratories. The resulting neighbor-joining tree is visualized in Figure $2 \mathrm{~b}$. The sample from the Netherlands (ANb) showed $F_{S T}$ values not significantly different from 0 with two Maine populations (Cundy harbour and Boothbay Harbour) confirming the Netherlands as the probable origin of the introduction of the European flat oyster on this Northern American region of Maine (Loosanof, 1955). Although significant, the $F_{\mathrm{ST}}$ values between the North Atlantic sample from Norway (ANa) and each of the Northern American populations were small as well. The neighbor-joining tree clearly shows that the sample from Norway ( $\mathrm{ANa}$ ) is clustering (all the bootstrap values were superior to 50\%) with the samples from Nova Scotia, indicating a possible second distinct introduction from Europe. It should be noted however that this analysis is based on only two loci with probable null alleles. Hence, this should be seen as a preliminary indication only and such analysis should be extended with more loci.

\section{Assignment of Maine individuals}

Assignment of the 30 Maine individuals on the basis of their genotype was overall satisfactory (Table 5) even though this was based on 5 loci, and the genetic isolation between Maine and Nova Scotia populations is fairly recent. Nine individuals could not be definitively assigned to a population but 19 were correctly identified as originating 
from a Maine population only and 2 were assigned to another Maine population or to a Nova Scotia naturalized population. Among those 21 individuals, 15 were assigned to the specific Maine population they originated with either the highest likelihood (8 cases) or the second highest (7 cases). It should be noted that most of the individuals from Blue Hill Bay were assigned to another population of Maine or to a re-naturalized population in Nova Scotia. That particular population could have been founded with individuals originated from other parts of Maine and from California (Sam Chapman, per. comm). In addition, Blue Hill Bay is the Maine population the least different from the Canadian stocks (Figure 2a). The assignment results presented here show both promise as a forensics tool, and some limitations. With a larger database and more microsatellite loci, more definite results could probably be achieved. Nonetheless, the present tool would seem to be able to detect illegal importation of Maine oysters that could bring the Bonamia disease into Nova Scotia.

\section{First generation pedigree reconstruction}

Most of the kin groups detected in the 10 oyster collections were very small, ranging in size from 1 to 11 with an average of 2.5 individuals, indicating that overall, most individuals were unrelated to one another in every collection. However, at least some of these small proposed kin groups appeared to be real, because in 6 out of the 10 populations, the kin group partition score based on the real genotype data was higher than seen in any of the 100 genotype randomization trials (Table 6). Not surprisingly, every hatchery population seemed to comprise at least a few truly related individuals (i.e. full or half-sibs). This was particularly the case for the Port Medway and Cape Sable 
collections. This is in agreement with the observations of Li \& Hedgecock (1998) and Boudry et al. (2002) who have noted that hatchery mass spawning typically contains large, over-represented family groups. In contrast, the naturalized populations of Cundy Harbor (Maine), Booth Bay (Maine) and Sambro (Nova Scotia) did not appear to contain related individuals. The last naturalized Maine collection, Blue Hill Bay, may have contained some related individuals but the signal from this analysis was fairly weak and the probability value was close to the $5 \%$ threshold. Some of the "naturalized" individuals in the Blind Bay (Nova Scotia) collection also appeared to be related to one another. This would be in agreement with the proposed explanation that this population is not truly self sustaining, and that the sampled individuals probably represented the last survivors of "escaped" cultured oysters from a grow-out site that operated there until a few years ago. The observation of truly related individuals in the Lake Lockhart (New Brunswick) collection is more surprising as this is a fairly large, self-sustaining population. To confirm this result, the genotype randomization trials were extended to 1000 , but with similar results. Partition scores as high or higher than the one observed on the real data, were only seen in 2 out of the 1000 trials. It is unlikely that oyster sampling in this location was somehow biased with respect to family composition as it took place with bottom dredging. This observation may be an indication that a few individuals may sometimes contribute a substantial (i.e. detectable) portion of the recruitment in the large but closed Lake Lockhart population.

\section{CONCLUSION}


The results of this study show that there is still a relatively high level of genetic diversity in the Canadian populations, but evidence of genetic erosion can be seen in the hatchery-propagated stocks. Some level of inbreeding increase occurs in hatchery populations of Ostrea edulis around the world, and there is evidence to suggest that excessive inbreeding can result in loss of fitness. For instance, Mallet \& Haley (1983) and Naciri-Graven et al. (2000) have observed that growth performance of offspring is negatively correlated with the relatedness of their parents. Using microsatellite loci to monitor inbreeding levels would appear to be warranted.

Increasing the number of loci available for use in $O$. edulis would be useful for continuing and future studies of genetic diversity and population structure in this species and for forensics studies given the presence of Bonamia in Maine and its absence so far in Nova Scotia and New Brunswick. Increasing sample size will also improve our ability to detect population and family structure more effectively.

Hatchery production for aquaculture allows the development of genetically improved strains but, simultaneously, loss of genetic diversity and potential inbreeding increase and inbreeding depression can have adverse effects. To manage inbreeding, it is important to utilize pedigree information when producing the next generation. Due to the reduced number of effective broodstock in mass spawning, where only a limited number of individuals contribute most of the offspring to the next generation, it may be wise to increase genetic variability in hatchery populations by maximizing the number of O. edulis broodstock used to produce larvae (at least 50 per lot, preferably 100) and pooling offspring from multiple spawning groups (i.e. multiple lots). The genetic impact of grading larvae and discarding the small ones, a common hatchery practice, should be evaluated. This practice may compound genetic erosion without really achieving any 
growth gain. The possibility of introducing individuals from naturalized populations at regular intervals in order to maintain genetic diversity and prevent further erosion of genetic diversity in Nova Scotia hatchery stocks should be evaluated as well.

Outbreeding of $O$. edulis should be carried out within Maritimes populations as opposed to more distant populations to reduce the possibility of disease transfer and as well to avoid the introgression of non-adapted genes into the actual stocks. In particular, history shows that only after a 30-year adaptation to Maine's cold environment did introduced European oysters survive in Nova Scotia's marginal winter conditions.

\section{ACKNOWLEDGEMENTS}

This study has been funded under the Aquaculture Collaborative Research and Development Program (ACRDP) and involved two hatcheries Lunenburg Shellfish Inc. and Har-Wen Farms in Port Medway. A technical report with raw data has been produced under that program (Vercaemer et al., 2003). It reflected an active collaboration between DFO and IFREMER (Institut français de recherche pour l'exploitation de la mer). We would especially like to thank Barry MacDonald (DFO Bedford Institute of Oceanography) for his support and Andrew Bagnall (NS Department of Agriculture and Fisheries - Aquaculture Division), Thomas Landry (Gulf Fisheries Centre) and Dale Wilbur, Gary Meyer and Susan Bower (DFO-Pacific Biological Station), Cathy Enright (Nova Scotia Agricultural College) and Chris Davis (Maine Aquaculture Training Institute) for collection of oysters. This manuscript was greatly enhanced from comments by two anonymous reviewers. 


\section{REFERENCES}

Alvarez, G., C. Zapata, R. Amaro \& A. Guerra. 1989. Multilocus heterozygosity at protein loci and fitness in the European oyster, Ostrea edulis L. Heredity 63:359-372.

Beattie, J.H., J. Perdue, W. Hershberger \& K. Chew. 1987. Effect of inbreeding on growth in the Pacific oyster Crassostrea gigas. J. Shell. Research 6:25-28.

Belkhir, K., P. Borsa, J. Goudet, L. Chikhi \& F. Bonhomme. 1996-2004. Genetix, Version 4.01. A Windows Program for Population Genetic Analysis. Laboratoire Génome, Populations, Interactions, CNRS UPR 9060, Université de Montpellier II, Montpellier, France.

Boudry, P., B. Collet, F. Cornette, V. Ghervouet \& F. Bonhomme. 2002. High variance in reproductive success of the Pacific oyster (Crassostrea gigas, Thunberg) revealed by microsatellite-based parentage analysis of multifactorial crosses. Aquaculture 204:283296.

Butler, K., C. Field, C.M. Herbinger \& B.R. Smith. 2004. Accuracy, efficiency and robustness of four algorithms allowing full-sib ship reconstruction from DNA marker data. Molecular Ecology 13:1589-1600. 
Cornuet, J.M., S. Piry, G. Luikart, , A. Estoup \& M. Solignac.1999. New methods employing multilous genotypes to select or exclude populations as origins of individuals. Genetics 153: 1989-2000.

Felsenstein, J. 1993. PHYLIP version 3.4. Distributed by the author. Department of genetics, University of Washington, Seattle, WA. Unpaginated.

Hedgecock, D. \& N.B. Okasaki. 1984. Genetic diversity within and between populations of American oysters (Crassostrea). Malacologia 25:535-549.

Hedgecokck, D. \& F. Sly.1990. Genetic drift and effective population sizes of hatcherypropagated stocks of the Pacific oyster, Crassostrea gigas, Aquaculture 88:21-38.

Hedgecock, D., W. Chow, \& R.S. Waples. 1992. Effective population numbers of shellfish broodstocks estimated from temporal variance in allelic frequencies. Aquaculture 108:251-232.

Hedgecock, D. 1994. Does variance in reproductive success limit effective population sizes of marine organisms? In Genetics and evolution of Aquatic Organisms. Edited by A.R. Beaumont. Chapman and Hall, London. pp. 122-134.

Herbinger, C.M., M.E. Reith \& T.R. Jackson. 2003. An overview of the use of DNA markers in aquaculture genetics. In "Molecular Genetics of Marine Organisms". Volume 
10 of "Recent Advances in Marine Biotechnology", Science Publishers of Enfield. pp. 367-419.

Launey, S. 1998. Marqueurs microsatellites chez l'huitre plate Ostrea edulis L.:

Caractérisation et applications à un programme de sélection pour une résistance au parasite Bonamia ostreae et à l'étude des populations naturelles. Thèse Institut National Agronomique Paris Grignon et IFREMER. 214 p.

Launey, S., M. Barre, A. Gérard \& Y. Naciri-Graven. 2001. Population bottleneck and effective size in Bonamia ostrae-resistant populations of Ostrea edulis as inferred by microsatellite markers. Genet. Res. Camb. 78:259-270.

Launey, S., C. Ledu, P. Boudry, F. Bonhomme \& Y. Naciri-Graven. 2002. Geographical Structure in the European oyster (Ostrea edulis L.) as revealed by microsatellite polymorphism. Journal of Heredity 93: 40-47.

Li, G. \& D. Hedgecock. 1998. Genetic heterogeneity, detected by PCR-SSCP, among samples of larval Pacific oysters (Crassostrea gigas) supports the hypothesis of large variance in reproductive success. Can. J. Fish. Aquat. Sci 55, 1025-1033.

Loosanoff, V.L., 1955. The European oyster in American waters. Science 121: 119-121.

Mallet, A.L. \& L.E. Haley, 1983. Effect of inbreeding on larval and spat performance in the American oyster. Aquaculture 33:229-235. 
Naciri-Graven, Y., S. Launey, N. Labayon, A. Gérard \& J.P. Baud. 2000. Influence of parentage upon growth in Ostrea edulis: evidence for inbreeding depression.

Nei, M. 1978. Estimation of average heterozygosity and genetic distance from a small number of individuals. Genetics 89:583-590.

Nei, M., T. Maruyama \& R. Chakraborty. 1975. The bottleneck effect and genetic variability in populations. Evolution 29: 1-10.

Newkirk, G.F. 1986. Controlled mating of the European oyster, Ostrea edulis. Aquaculture: 57: 111-116.

Newkirk, G., B.C. Muise \& C.E. Enright. 1995. Culture of the Belon oyster, Ostrea edulis, in Nova Scotia. In: Cold-water aquaculture in Atlantic Canada ( $2^{\text {nd }}$ edition). Edited by: A.D. Boghen. The Printing Press, Sackville, N.B. pp. 226-253.

Petit, R.J., A. El Mousadick \& O. Pons. 1998. Identifying populations for conservation on the basis of genetic markers. Conservation Biology 12: 844-855. htpp://www.pierroton.intra.fr/genetics/labo/Software/Contrib Reynolds, J., B.S. Weir \& C.C. Cockerman. 1983. Estimation of the coancestry coefficient: a basis for a short-term genetic distance. Genetics 105:767-779. 
Saavedra, C. \& A. Geera. 1996. Allozyme heterozygosity, founder effect and fitness traits in a cultivated population of the European oyster, Ostrea edulis. Aquaculture 139:203-224.

Saitou, N. \& M. Nei. 1987. The neighbor-joining method: A new method for reconstructing phylogenetic tree. Mol. Biol. Evol. 4:406-425.

Smith, B.R., C.M. Herbinger \& H.R. Merry. 2001. Accurate partition of individuals into full sib families from genetic data without parental information. Genetics 158:1329-1338.

Spares, A.D. \& M.J. Dadswell. 2001. Goat lake, a warm water, estuarine refugee for mollusks on the south shore of Nova Scotia. Proc. N.S. Inst. Sci. 41(4) pp. 134-148.

Van Oosterhout, C., W.F. Hutchinson, D.P.M. Wills \& P. Shipley., 2004. Program note Micro-Checker: software for identifying and correcting genotype errors in microsatellite data. Molecular Ecology Notes 4: 535-538.

Vercaemer, B., K. Spence, E. Kenchington, A. Mallet \& J. Harding. 2003. Assesment of genetic diversity of the European oyster (Ostrea edulis) in Nova Scotia using microsatellite markers. Canadian Technical Report of Fisheries and Aquatic Science No. 2453.

Weir, B.S. \& C.C. Cockerham 1984. Estimating F-statistics for the analysis of population structure. Evolution 38: 1358-1370. 
Welsh, W.R. 1964. The European oyster, Ostrea edulis, in Maine. Proceedings of the National Shellfisheries Association. 54:7-23.

Zouros, E. \& D.W. Foltz. 1984. Possible explanations of heterozygote deficiency in bivalve molluscs. Malacologia 25:583-591. 
Figure 1. Map showing sampling locations and transfers of Ostrea edulis (long thin arrows indicate transfers to and whithin Nova Scotia and to New Brunswick)

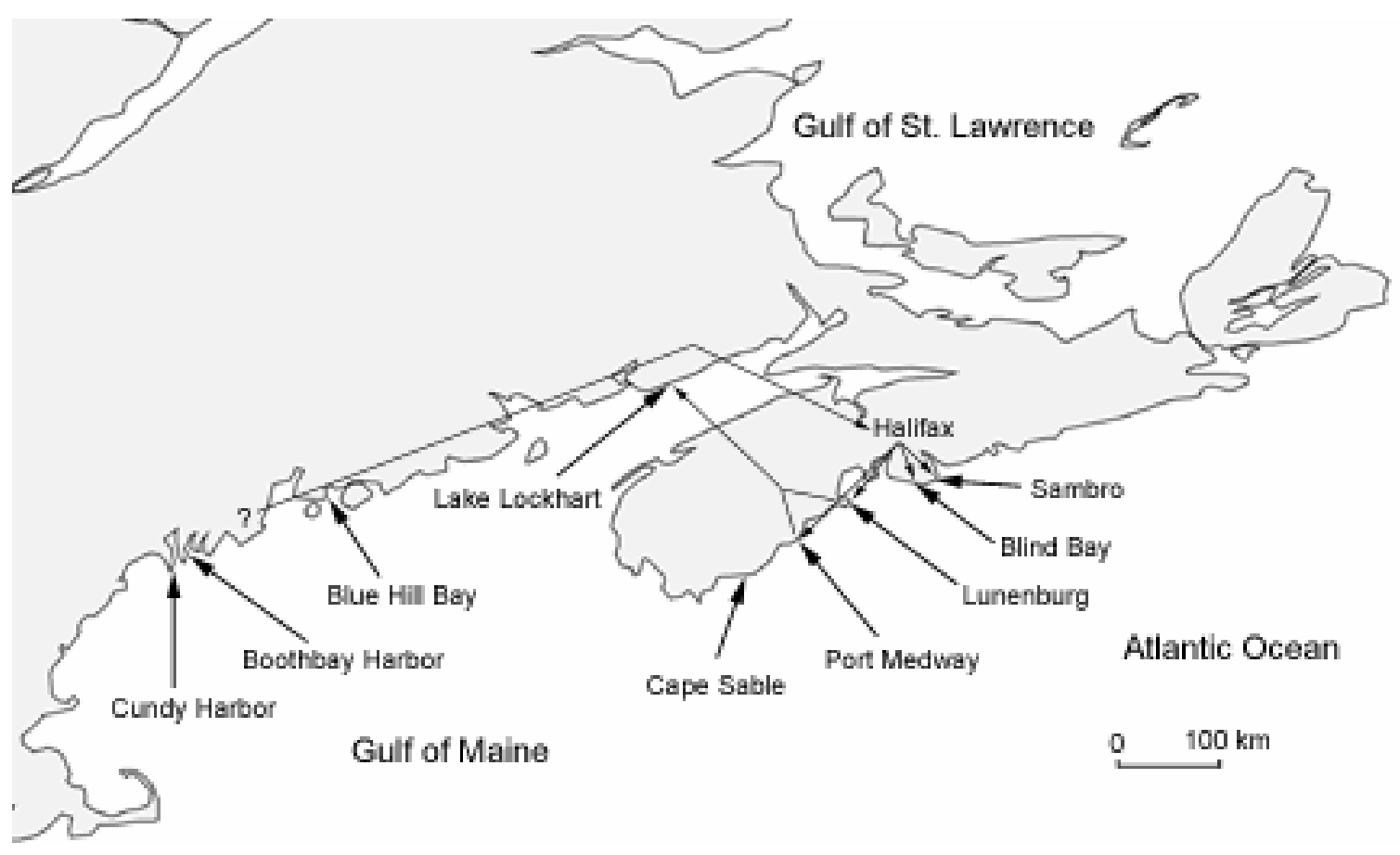


Figure 2. Unrooted Neighbor-Joining tree (Saitou and Nei, 1987) obtained from coancestry genetic distances (PAC: Pacific Coast, LUN: Lunenburg, MED: Port Medway, CAS: Cape Sable, BLB: Blind Bay, SAM: Sambro, LLO: Lake Lockhart, CUH: Cundy Harbor, BOH: Boothbay Harbor, BHB: Blue Hill Bay).

a. Canadian and Maine populations (5 loci)

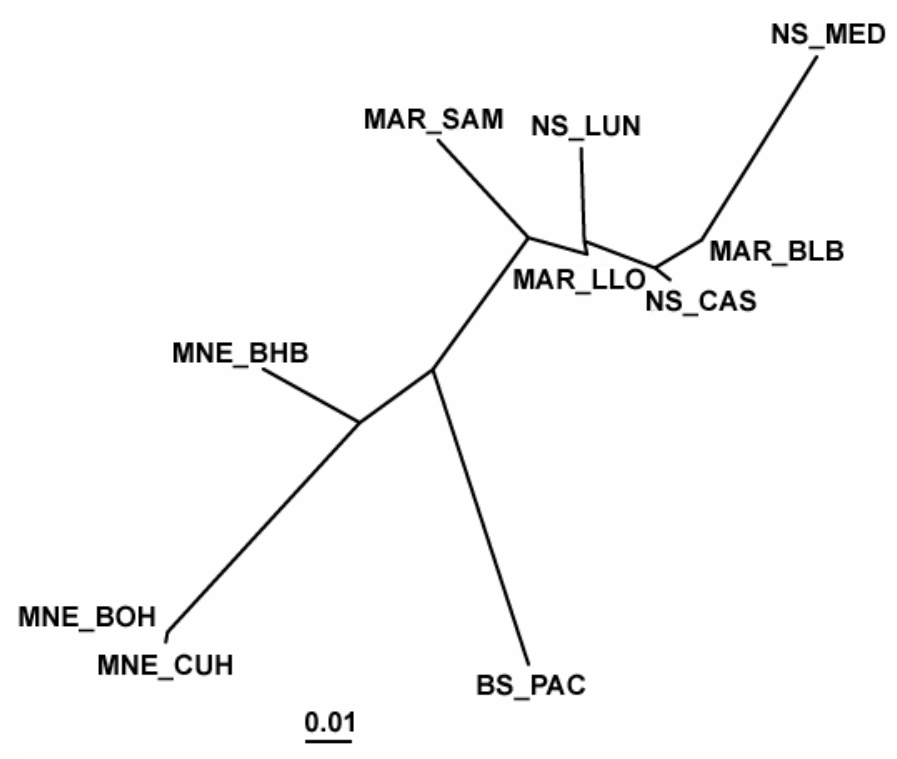


b. Canadian and North Atlantic European populations (2 loci)

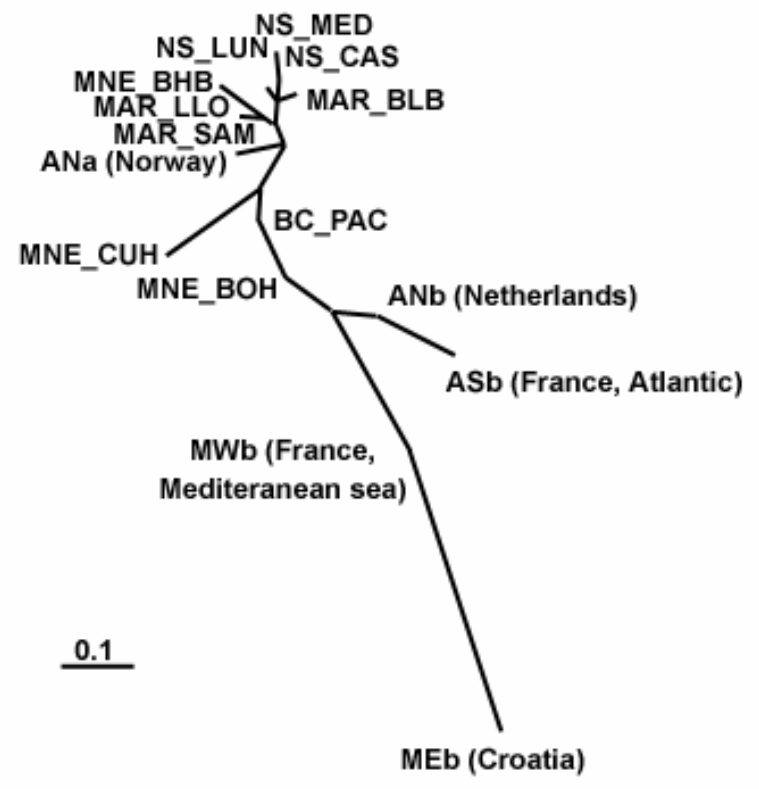


Table 1. Number of individuals genotyped and the number of observed alleles for the combined Canadian and Maine populations. Data for the Northern European populations of Ostrea edulis was obtained from Launey (1998).

\begin{tabular}{|c|c|c|c|c|c|c|}
\hline \multirow[b]{2}{*}{ Locus } & \multicolumn{2}{|c|}{ Canadian populations } & \multicolumn{2}{|c|}{ Maine populations } & \multicolumn{2}{|c|}{$\begin{array}{l}\text { North European populations } \\
\text { (Launey, 1998) }\end{array}$} \\
\hline & $\begin{array}{l}\text { Number of } \\
\text { individuals }\end{array}$ & $\begin{array}{l}\text { Observed nb. } \\
\text { of alleles }\end{array}$ & $\begin{array}{l}\text { Number of } \\
\text { individuals }\end{array}$ & $\begin{array}{l}\text { Observed nb. } \\
\text { of alleles }\end{array}$ & $\begin{array}{l}\text { Number of } \\
\text { individuals }\end{array}$ & $\begin{array}{l}\text { Observed nb. } \\
\text { of alleles }\end{array}$ \\
\hline OeduU2 & 356 & 26 & 139 & 28 & 254 & 33 \\
\hline OeduT5 & 427 & 21 & 239 & 27 & 254 & 26 \\
\hline OeduH15 & 403 & 14 & 236 & 14 & 254 & 17 \\
\hline OeduO9 & 426 & 12 & 246 & 17 & 254 & 21 \\
\hline OeduJ12 & 425 & 23 & 251 & 22 & 254 & 27 \\
\hline Average & & 19.2 & & 21.6 & & 24.8 \\
\hline
\end{tabular}


Table 2. Sample size ( $\mathrm{n}$ ) and total number of alleles (- corrected number for sample size) per locus for each population of Ostrea edulis. NS hatcheries, Maritimes naturalized, and Maine naturalized combined for comparison. Hatcheries: BC_PAC: Pacific Coast, BC, NS_LUN: Lunenburg, NS, NS_MED: Port Medway, NS, NS_CAS: Cape Sable, NS, Maritimes naturalized: MAR_BLB: Blind Bay, NS, MAR_SAM: SambroNS, MAR_LLO: Lake Lockhart, NB, Maine naturalized: MNE_CUH: Cundy Harbor, ME, MNE_BOH: Boothbay Harbor, ME, MNE_BHB: Blue Hill Bay, ME.

\begin{tabular}{|c|c|c|c|c|c|c|c|}
\hline \multirow[t]{2}{*}{ Population } & \multirow[t]{2}{*}{$\mathrm{n}^{(1)}$} & \multicolumn{6}{|c|}{ Number of alleles } \\
\hline & & OeduU2 & OeduT5 & OeduH15 & OeduO9 & OeduJ12 & Average \\
\hline BC_PAC & 30 & $16-16$ & $12-11.93$ & $8-8.00$ & $9-9.00$ & $11-11.00$ & $11.2-11.20$ \\
\hline NS_LUN & 68 & $14-12.62$ & $12-11.39$ & $9-7.86$ & $9-8.16$ & $13-11.59$ & $11.4-10.32$ \\
\hline NS_MED & 39 & $15-13.95$ & $13-11.44$ & $8-7.89$ & $9-8.26$ & $9-8.02$ & $10.8-9.91$ \\
\hline NS_CSA & 125 & $18-14.42$ & $17-11.85$ & $7-6.87$ & $10-8.37$ & $16-8.92$ & $13.6-10.09$ \\
\hline $\begin{array}{c}\text { Total NS } \\
\text { hatcheries }\end{array}$ & 233 & 18 & 17 & 9 & 11 & 20 & 13.6 \\
\hline MAR_BLB & 36 & $11-10.91$ & $12-12.00$ & $8-7.77$ & $7-6.86$ & $7-6.84$ & $9.0-8.88$ \\
\hline MAR_SAM & 57 & $15-14.21$ & $17-14.72$ & $10-9.37$ & $12-10.53$ & $15-11.53$ & $13.8-12.07$ \\
\hline MAR_LLO & 148 & $24-18.44$ & $18-14.63$ & $11-9.24$ & $11-9.05$ & $18-12.70$ & $16.4-12.15$ \\
\hline $\begin{array}{c}\text { Total Maritimes } \\
\text { naturalized }\end{array}$ & 188 & 25 & 19 & 12 & 12 & 20 & 17.6 \\
\hline MNE_CUH & 100 & $22-20.26$ & $23-16.39$ & $14-11.88$ & $16-12.10$ & $19-15.02$ & $18.8-15.13$ \\
\hline MNE_BOH & 89 & $22-19.84$ & $25-18.58$ & $11-10.14$ & $12-10.45$ & $21-17.44$ & $18.2-15.29$ \\
\hline MNE_BHB & 65 & $21-17.42$ & $16-13.89$ & $9-8.71$ & $12-9.98$ & $15-12.16$ & $14.6-12.43$ \\
\hline $\begin{array}{l}\text { Total Maine } \\
\text { naturalized }\end{array}$ & 257 & 28 & 27 & 14 & 17 & 22 & 21.6 \\
\hline
\end{tabular}


(1) The sample size is given here as an indication only; not all individuals amplified at each locus. The BC_PAC collection is the smallest collection; hence corrected number of alleles is equal to the actual number of alleles for all loci but T5 where for the MAR_BLB collection, 29 samples only amplified at that particular locus. 
Table 3. Statistics per population of Ostrea edulis: sample size (n), non biased expected heterozygosity $\mathrm{H}_{\mathrm{e}}$ (Nei, 1978), observed heterozygosity $\mathrm{H}_{0}$, and HardyWeinberg Equilibrium deviations estimated by $\mathrm{F}_{\text {is. }}$.

\begin{tabular}{|c|c|c|c|c|c|c|c|c|c|}
\hline \multirow{2}{*}{ Population } & \multirow{2}{*}{$\mathrm{n}$} & \multirow{2}{*}{$\mathrm{H}_{\mathrm{e}}$} & \multirow{2}{*}{$\mathrm{H}_{\mathrm{o}}$} & \multicolumn{6}{|c|}{$F_{\text {is }}$} \\
\hline & & & & All loci & OeduU2 & OeduT5 & OeduH15 & OeduO9 & OeduJ12 \\
\hline BC_PAC & 30 & 0.860 & 0.827 & $0.040^{\star}$ & 0.134 & -0.012 & 0.044 & -0.057 & $0.079 * \star$ \\
\hline NS_LUN & 68 & 0.810 & 0.670 & $0.175^{\star \star \star}$ & 0.003 & 0.007 & $0.459 * \star \star$ & $0.130^{*}$ & $0.335^{\star \star}$ \\
\hline NS_MED & 39 & 0.786 & 0.736 & $0.064^{\star *}$ & 0.002 & -0.094 & 0.199 & -0.166 & $0.454^{\star \star \star}$ \\
\hline NS_CSA & 125 & 0.795 & 0.695 & $0.121^{\star \star \star}$ & $0.059^{*}$ & $0.024^{\star *}$ & $0.382^{\star \star \star}$ & $-0.083^{\star}$ & $0.290 * \star \star *$ \\
\hline MAR_BLB & 36 & 0.773 & 0.678 & $0.124^{\star \star *}$ & $-0.063^{*}$ & -0.018 & $0.406^{\star \star \star}$ & 0.052 & $0.357^{\star \star}$ \\
\hline MAR_SAM & 57 & 0.855 & 0.706 & $0.176^{\star \star \star}$ & -0.018 & $0.019 * *$ & $0.485^{\star \star \star}$ & 0.087 & $0.344^{\star \star \star}$ \\
\hline MAR_LLO & 148 & 0.821 & 0.707 & $0.139 * \star \star$ & 0.076 & -0.024 & $0.547 * \star \star$ & -0.060 & $0.190^{\star \star *}$ \\
\hline MNE_CUH & 100 & 0.876 & 0.720 & $0.179^{\star \star \star}$ & 0.051 & 0.056 & $0.585^{\star \star \star}$ & 0.049 & $0.159 * \star$ \\
\hline MNE_BOH & 89 & 0.889 & 0.793 & $0.110^{\star * *}$ & -0.031 & 0.017 & $0.447^{\star \star \star}$ & -0.019 & $0.155^{\star \star \star}$ \\
\hline MNE_BHB & 65 & 0.854 & 0.753 & $0.119^{\star \star \star}$ & 0.081 & -0.007 & $0.420 * \star \star$ & $-0.079^{\star}$ & $0.202^{\star \star}$ \\
\hline
\end{tabular}




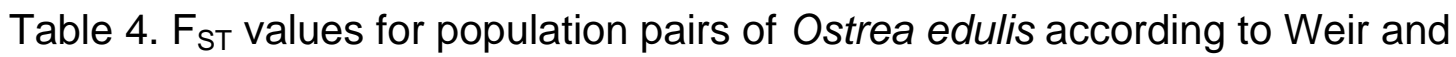
Cockerham (1984).

\begin{tabular}{|c|c|c|c|c|c|c|c|c|c|}
\hline \multicolumn{10}{|l|}{ Population } \\
\hline (FsT) & BC_PAC & NS_LUN & NS_MED & NS_CSA & MAR_BLB & MAR_SAM & MAR_LLO & MNE_CUH & MNE_BOH \\
\hline NS_LUN & 0.038 & & & & & & & & \\
\hline NS_MED & 0.049 & 0.027 & & & & & & & \\
\hline NS_CSA & 0.048 & 0.019 & 0.021 & & & & & & \\
\hline MAR_BLB & 0.057 & 0.018 & 0.026 & $0.007^{\mathrm{NS}}$ & & & & & \\
\hline MAR_SAM & 0.041 & 0.028 & 0.050 & 0.024 & 0.029 & & & & \\
\hline MAR_LLO & 0.033 & 0.011 & 0.022 & 0.011 & $0.013^{\mathrm{NS}}$ & 0.021 & & & \\
\hline MNE_CUH & 0.024 & 0.046 & 0.054 & 0.046 & 0.054 & 0.038 & 0.036 & & \\
\hline MNE_BOH & 0.019 & 0.043 & 0.051 & 0.045 & 0.056 & 0.035 & 0.035 & $0.003^{\mathrm{NS}}$ & \\
\hline MNE_BHB & 0.038 & 0.037 & 0.040 & 0.039 & 0.048 & 0.028 & 0.026 & 0.023 & 0.019 \\
\hline
\end{tabular}


Table 5. Assignment of 3 samples of 10 random Ostrea edulis individuals from Maine using GENECLASS (MNE_CUH: Cundy Harbor, ME, MNE_BOH: Boothbay Harbor, ME, MNE_BHB: Blue Hill Bay, ME, MAR_SAM: Sambro, NS, MAR_LLO: Lake Lockhart, NB)

\begin{tabular}{|c|c|c|c|c|}
\hline $\begin{array}{l}\text { Sample } \\
\text { size }\end{array}$ & $\begin{array}{l}\text { Number } \\
\text { of loci }\end{array}$ & $\begin{array}{l}\text { (\#) classified with the highest } \\
\text { probability in }\end{array}$ & Notes & Real origin \\
\hline 10 & 5 & $\begin{array}{l}\text { (4) MNE_CUH } \\
\text { (3) MNE_BOH also classified in MNE_CUH } \\
\text { (1) BOH also classified in MNE_CUH and } \\
\text { MNE_BHB } \\
\text { (2) unclassified }(P<0.01)\end{array}$ & $\begin{array}{l}\text { No individual } \\
\text { classified outside } \\
\text { of Maine }\end{array}$ & MNE_CUH \\
\hline 10 & 5 & $\begin{array}{l}\text { (2) MNE_BOH } \\
\text { (2) MNE_BOH also classified in MNE_CUH } \\
\text { (2) MNE_CUH } \\
\text { (4) unclassified }(P<0.01)\end{array}$ & $\begin{array}{l}\text { No individual } \\
\text { classified outside } \\
\text { of Maine }\end{array}$ & MNE_BOH \\
\hline 10 & 5 & $\begin{array}{l}\text { (3) MNE_CUH } \\
\text { (1) MNE_BOH } \\
\text { (1) MNE_CUH also classified in MNE_BHB } \\
\text { (2) MNE_CUH also classified in MNE_BHB, } \\
\text { MNE_BOH, MAR_LLO and/or MAR_SAM } \\
\text { (3) unclassified }(P<0.01)\end{array}$ & $\begin{array}{l}20 \% \text { classified } \\
\text { outside of Maine ( } 2 \\
\text { re-naturalized } \\
\text { populations) }\end{array}$ & MNE_BHB \\
\hline
\end{tabular}


Table 6. Kin group partition of the Ostrea edulis collections

\begin{tabular}{l|l|l}
\hline Population & \multicolumn{1}{|c}{$\mathrm{n}^{(1)}$} & \multicolumn{1}{|c}{$\begin{array}{c}\text { Probability of seeing a score as } \\
\text { high or higher in genotype } \\
\text { randomization trials }\end{array}$} \\
\hline Hatcheries: & 30 & $<1 \%$ \\
BC_PAC: Pacific Coast, BC & 68 & $<1 \%$ \\
NS_LUN: Lunenburg, NS & 39 & $<1 \%$ \\
NS_MED: Port Medway, NS & 123 & $<1 \%$ \\
NS_CAS: Cape Sable, NS & 31 & $<1 \%$ \\
Maritimes naturalized: & 34 & NS (50\%) \\
MAR_BLB: Blind Bay, NS & 139 & $<3 \%(2)$ \\
MAR_SAM: Sambro, NS & 78 & NS (65\%) \\
MAR_LLO: Lake Lockhart, NB & 78 & NS (16\%) \\
Maine naturalized: & $5 \%$ \\
MNE_CUH: Cundy Harbor, ME & 78 \\
MNE_BOH: Boothbay Harbor, ME & 78 & \\
MNE_BHB: Blue Hill Bay, ME & 64 &
\end{tabular}

(1) Sample size

(2) Probability estimated on 1000 randomization trials, as opposed to 100

in the other collections 